$20 \mid 2019$

Sedition, Sexuality, Gender, and Gender Identity in South Asia

\title{
Queer intimacy during seditious times: revisiting the case of Ramchandra Siras
}

\section{Nishant Shahani}

\section{(2) OpenEdition}

\section{Journals}

Electronic version

URL: https://journals.openedition.org/samaj/5230

DOI: $10.4000 /$ samaj.5230

ISSN: 1960-6060

Publisher

Association pour la recherche sur l'Asie du Sud (ARAS)

Electronic reference

Nishant Shahani, "Queer intimacy during seditious times: revisiting the case of Ramchandra Siras", South Asia Multidisciplinary Academic Journal [Online], 20 | 2019, Online since 16 April 2019, connection on 21 September 2021. URL: http://journals.openedition.org/samaj/5230 ; DOI: https://doi.org/ $10.4000 /$ samaj.5230

This text was automatically generated on 21 September 2021

\section{(i) 89

This work is licensed under a Creative Commons Attribution-NonCommercial-NoDerivatives 4.0 International License. 


\title{
Queer intimacy during seditious times: revisiting the case of Ramchandra Siras
}

\author{
Nishant Shahani
}

I always wanted to be a writer. A writer of science, like Carl Sagan

I loved Science, Stars, Nature, but then I loved people without knowing that people have long since divorced from nature. Our feelings are second handed. Our love is constructed. Our beliefs colored. Our originality valid through artificial art. It has become truly difficult to love

without getting hurt. The value of a man was reduced to his immediate identity and nearest possibility. To a vote. To a number. To a thing. Never was a man treated as a mind. As a glorious thing made up of star dust. In every field in studies, in streets, in politics, and in dying and living. Rohith Vemula

1 It is not without significance that Rohith Vemula's suicide note articulated the violence of the caste system and the vision of the Ambedkar Student Association through a language of desire-the difficulty of loving "without getting hurt." In this essay I want to return to the tragedy of Vemula's suicide and the campus activisms that his death triggered as the occasion to revisit another suicide-or what Arundhati Roy more appositely terms "institutional murder" (2016) - on a university campus: the case of gay professor Ramchandra Siras at Aligarh Muslim University.

2 I want to ask what it might mean to retrospectively re-think the case of Siras through the language of political and public desire that Vemula's case at the University 
Hyderabad (UOH) and the Jawaharlal Nehru University (JNU) student protests present. Siras, whose apparent suicide in 2002 as a consequence of forced outing has thus far been framed almost exclusively as a case of privacy violation, buttressing activist urgency around the repeal of Section 377 (Indian Penal Code 1860)-the "anti-sodomy" law that became the locus of resistance of LGBT activists in India over the past three decades, and that was struck down as inapplicable to homosexual sex as of September 6, 2018 by the Supreme Court of India. I want to suggest that these dual suicides on University campuses, when viewed in tandem, offer a way of framing queer politics through a more assemblaged lens that is not limited to the discourse of privacy rights, or to the concerns of class and caste elites.

3 My goal in re-thinking the Siras case via more contemporary discourses around "sedition" on university campuses is not to point out superficial similarities or argue for simple a simple analogy between "queer" and "Dalit" (which only always reifies the caste and class privilege of the former and the heterosexuality of the latter). Neither is it to simply underscore the similarities between a tale of two suicides that both take place under the aegis of universities that have become flashpoints for contestations around caste, sexuality, communalist violence, and discourses of compulsory nationalism. Undeniably, the lures of analogy beckon when positing Siras and Vemula in proximity with one another, through easy temptations of "just like" formulations: for example, the love of writing and investments in aesthetics, the struggles against reification in which "value" is reduced to identity (untouchable and gay), the desire to love without hurt, the rejection of mind/body dualisms, the "fatal accidents" of birth that mark their precarity, the attempts to transgress the "nearest possibilities" presented to them, and ultimately, the loneliness that proves too painful and violent to bear. But to analogize this "likeness" between Siras and Vemula is to ironically repeat the very modes of injury that reduce them into votes, numbers, or things, to use Vemula's own language. Analogies use the assumed internal coherence of one category as the fulcrum to level the other, reducing it to, in Vemula's words, "immediate identity" and what is already presumably known.

4 My purpose in this essay, however, is to move beyond the lures of analogy. The occasion for this refracted and retrospective reading of Siras is mediated by the release of the film Aligarh (Mehta:2016) just one month after Vemula's death, and a few weeks after the JNU controversy in which students protesting capital punishment were arrested and charged with sedition by the Delhi police. On the basis of the professor's life during the months leading up to his death, I offer a critique of the film to ask what is lost from our analytical and political categories when the Siras case is read exclusively as one that belongs to a genealogy of intimacy and illegal privacy violation. In what ways is queer intimacy predicated on constitutive violence of class, caste, and communalist bracketing? Even though my analysis performs a fairly close textual reading, my arguments transcend the specifics of both cases to gesture toward the following question: what does it mean to argue for queer national belonging through state-sanctioned structures of law at the very historical moment when the rhetoric of sedition and compulsory nationalism is mobilized as a way to violently erase dissent? Before I grapple with this question, I want to offer a few qualifying comments on the essay's methodological interventions and the political/theoretical contexts of sedition that subtend both the Siras and Vemula cases. 


\section{“Assembling" critique}

5 The epistemological weight of the above question might admittedly seem too broadly ambitious in scope, especially when filtered through a close reading and critique of a single cultural text, as I attempt in this essay. But my methodological investments in textual critique are not entirely divorced from conceptual concerns. In my analysis of Aligarh (Mehta:2016), the place of critique functions both as a kind of reading practice and as an intervention into state-centered logics of queer activism tied to the repeal of Section 377 (Indian Penal Code 1860). In asking what is left (out) of queer appeals to the state, the conventional riposte is most often articulated through logics of rhetorical pragmatism and political instrumentality: "If not this, then what is the alternative?" The demand for "real" politics that is implicitly opposed to "merely" symbolic critique can function to obviate the work of a broader political imagination that dares to ask what might exist beyond the altar of equality before the law (an equality that is always qualified by the limits of its own regulatory productions). In their interrogation of state-centered legalism, Wendy Brown and Janet Halley (2002) theorize the notion of critique as a reading practice that functions as a useful tool to describe both the methodological and conceptual thrust of this essay. Brown and Halley point to how the critique of state-sanctioned legalism is often accused of "being ... intellectually indulgent, easier than fixing things or saying what is to be done" (p. 25). In other words, critique gets framed as apolitical or abstractly theoretical as opposed to the material muscularity of legal change. Rather than a defensive posturing against critique's ostensibly more tangential relation to "the real," Brown and Halley argue for an embrace of its performative uncertainty.

6 The knowledge produced by critique is precarious in that its outcomes are not predictable in advance through the promised assurance of policy reversals or legal repeals-in fact, the consequences of critique might seem permanently deferred or momentarily suspended. And yet, such forms of epistemological stuttering do not foreclose critique's reparative or pleasure producing possibilities. Brown and Halley (2002) thus write: "Not knowing what a critique will yield is not the same as suspending all political values while engaged in critique" (p. 27). In fact, the unpredictability of these forms of not-knowing brings its own kinds of textual pleasures since "there can be a kind of euphoria in being released to think critically about something that one experiences as constraining, limited, or gagging" (p. 29). The attention to critique as a source of euphoria puts it in the same methodological vicinity as Eve Sedgwick's (2003) theorization of reparative reading that is, according to her, "keenly pleasure-oriented" (p. 144). Sedgwick offers the notion of reparative reading as an alternative to those critical practices that are mired in "paranoid thinking"-the hermeneutic of exposure that is always already vigilant for the "bad news" of hegemony that must be exposed at all costs. Since paranoid readings are implicated in anticipatory methods that only confirm what they suspect, they result in critical tendencies that have tautological relations to questions of temporality. In contrast, reparative reading practices are more mutable in their temporal logics. They recognize how texts are recursively structured by the past, but also allow for readings in which "the future may be different from the present" (Sedgwick 2003:146). Critique, in other words, even when not offering some stable ground for political "solutions" can be, in Sedgwick's (2003) words "additive and accretive" (p. 129) in scope. My reading of Aligarh (Mehta:2016) in this essay mobilizes 
reparative critique in this sense, as a way of piecing together "fragments and partobjects" into what Sedgwick (2003) calls "something like a whole-though ... not necessarily like any preexisting whole" (p. 128). This qualifier is crucial since reparative critique as I mobilize it does not culminate in the certitudes of what Ashley Tellis and Sruti Bala (2015) call "an illusory point of arrival" (p. 21) that marks state-centered queer activism in India. Reparative critique, in refusing to simply lapse back into the rigid tautologies of a "preexisting whole," aims to articulate possibilities beyond the entrenched faith in "liberal legalism" (Brown and Halley 2002:5) and state protection.

But there is yet another sense in which my methodological engagements "assemble and repair" (Sedgwick 2003:128) fragments, even while resisting the rigid temporalities that would merge these discrete parts into a reified whole. Sedgwick's use of "assemble" (as opposed to "unify") and my mobilization of "assemblage" at the outset, while not synonymous, do function in the same methodological vicinity. In the field of queer theory, the most noteworthy use of "assemblage" is associated with the work of Jasbir Puar whose critique of intersectionality and its rigid co-options is useful for my own investments in arguing for more "assemblaged" understandings of caste with queerness. Even while intersectionality remains a politically imperative project, its standardization and academic institutionalization have resulted in its mobilization as a way to simply foreground supplemental subject positions (in which a performance of radicalism gets cathected through the multiplication of identities). Thus in arguing for an assemblaged lens, I am making the case for a kind of methodological critique that does not simply bestow political or epistemological authority on marginal identities. Nor do I simply want to make a politically imperative but fairly well-rehearsed call for broader alliances within progressive social movements. Instead of instrumentalizing intersectionality as a performance of political capital, an assemblaged method theorizes social categories and identities, as "events, actions, and encounters between bodies, rather than simply entities and attributes of subjects" (Puar 2012:58).

\section{Sedition, security and the politics of desire}

8 If we are to understand the assemblaged logics beyond identity politics, Puar (2012) suggests a critical focus on the "patterns" and "intensified relations [that] have given new capacities to ... entities" rather than "the entities themselves" (p. 60-61). Puar's attention to the "assemblage of the event-space" (p.13) is apposite for my purposes in which the $21^{\text {st }}$-century politics of sedition function as the site through which patterns of relations between caste and sexuality can be mapped and articulated. In what sense do the politics of sedition become the "event-space" for an assemblaged understanding of caste and sexuality? Before detailing the range of actors and "event-spaces" that subtend contemporary mobilizations of sedition by the Indian state, I want to point out the term's capacious reach to unpack its implications for scholarship and activism around gender and sexuality.

9 In her analysis of the relationship between sedition and liberal democracy India, Anushka Singh (2018) theorizes sedition as a kind of performative excitable speech "which is forbidden for exceeding the limit of legitimate criticism and, therefore, not protected by the right to freedom of speech and expression" (p.3). The ideological limits of speech on account of its seditious potential-as that which exists outside the bounds of "legitimate" or "reasonable" criticism - resonate with the injunctions 
against critique-as-method on account of its threats to liberal political value. If critique, as Brown and Halley (2002) remind us, is "risky" and at times, even "a disruptive, disorienting, ... destructive enterprise of knowledge" (p. 28), the managing of seditious discourse similarly threatens to disrupt democracy's claims to freedom and liberty. Democracies, writes Singh (2018), are "fraught" since they must manage "conflicting tendencies which inhere in the logic of 'democracy' and the logic of the "state"' (p. 2). Singh (2018) thus suggests that in the Indian context, "coagulating state security" (p. 2) plays a crucial role in rationalizing the legal restrictions around speech that is considered anti-national.

If seditious discourse constitutes an assemblaged "event-space," I want to foreground how the notion of desire is also central to its constitutive elements. In a powerful speech at a sit-in at JNU entitled "What the Nation Really Needs to Know," Lawrence Liang, co-founder of the Bangalore Alternative Law Forum, articulated the assemblage between sedition and desire only a few weeks after criminal cases were registered against students accused of making anti-national slogans in support of Kashmir's selfdetermination. In his speech, Liang returns to the colonial state's wielding of sedition law via Section 124-A (Indian Penal Code 1860), through which Gandhi was accused of treasonous activity. Quoting Gandhi, Liang (2016) points to the language of coerced desire at the heart of seditious law: "Affection cannot be manufactured or be regulated by the law; one should be free to give full expression to their disaffection." ${ }^{1}$ In Gandhi's protest, compulsory "affection" works in tandem with the demand for the production of loyal national subjects. But in response to compulsory affection for the nation, Liang does not suggest the eschewal of this emotive language of desire that is central to seditious discourse, however coercive and violent it might be. Instead, he points to the discourse of love that is endemic to dissent. Liang encourages a reading of Gandhi's protest as an illustration of Socratic love that framed its own protests against the sovereign state as a kind of dissenting disidentification. Dissent then becomes a kind of love rather than a form of treachery. Liang (2016) thus remarks: "What it means to be seditious-let's take it away from the language that has been given to us of national/ anti-national, or traitor, betrayal etc. and argue instead (for) another kind of politics that reclaims what we may mean to think about a different form of love." ${ }^{2}$ In his speech, Liang argues for a politics of reclamation-of retaining sedition's proximity to desire as a way of expressing dissent as a "queer" kind of love that is not mandated by the state. To bring these broader questions back to my reading of Aligarh (Mehta:2016), what is lost from maps of contestation when queer love can only be cathected via state recognition? What is missed when "seditious" practices of (dis)affection are bracketed within queer scenes of arrival? How might reparative critique return us to pleasures that can be gleaned from disaffection?

\section{Contexts of critique}

11 Refracting the "cases" of Siras and Vemula through one another requires some more context on the broader "event-spaces" that would permit an assembled reading. In "On the Case," Lauren Berlant (2007) usefully differentiates between the "genres" of the case and the event, suggesting that "a case is what an event can become" (p.9). The emphasis on becoming ties the logics of the case to the assemblage whose patterns are not organized into a seamless whole, but in which putatively discrete elements are 
drawn into one another's social and affective fields, allowing for new affinities and ways of being. Thus the contexts that I detail below cannot be read simply as sequential descriptions of truncated and spectacular events; instead, they constitute the assembled logics of security, seduction, and sedition on which critique is predicated.

In 2016, the Hindu Right's experiments in saffronization, privatization, anti-affirmative action politics, and compulsory nationalism all came to head in a tragic and violent fashion when Rohith Vemula, a Dalit PhD student at the University of Hyderabad, committed suicide. A few months before the tragic incident, Vemula and five other activist friends were suspended and prevented from entering their hostels and using University public spaces on account of their participation in ostensibly "anti-national" activities on campus. As members of the Ambedkar Students Association (ASA), Vemula and his friends had frequently clashed on campus with the Akhil Bharatiya Vidyarthi Parishad (ABVP), the student chapter of the right-wing Hindu Nationalist Rashtriya Swayamsevak Sangh (RSS). Ironically, it was not caste discrimination, but the ABVP's communalist agenda-what Vemula called "the bloodthirsty nationalism"- that sparked the central conflict between the two groups at the University of Hyderabad. In 2015, the ASA protested against the death sentence of Yakub Memon, a Muslim who was accused of collaborating with the masterminds behind the 1993 bomb blasts in Mumbai. Given that the largest percentage of Indian citizens killed by capital punishment were Dalits and Muslims, the ASA planned a protest called "Resistance Gathering against Capital Punishment: In the Wake of Death Sentence to Yakub Menon." A poster at a rally held up by one of the ASA students read: "Public conscience is Brahmin conscience. Satisfy with Muslim blood: ASA-UOH" (Donthi 2016). Much of this activism in the service of anti-communalist ideology was a way of distancing Dalit politics from co-option by Hindutva logic against the fabricated common enemy of the Muslim minority. A member of the ASA articulated these coalitional endeavors as efforts in "creating a universal language of discrimination" in order to counter the supremacy of Hindu nationalist ideology. While the ASA's protests were branded as anti-national and anti-Hindu, the real threat on the campus that the group posed was their ability to, in Arundhati Roy's (2016) words, make "connections between caste, capitalism, and communalism." ${ }^{3}$

In a poignant photo that circulated in the news media following his death, Vemula is pictured with two friends carrying assorted remnants of their private possessions: a suitcase, a mattress, a blanket, a bag full of clothes, a couple of towels. The "private," in this instance, quite literally spills over into the public. The humble belongings in their hands are dwarfed by a giant-sized portrait of the Dalit leader, B. R. Ambedkar held by Vemula. Epitomizing a demand for accountability in the midst forced precarity, the photograph also illustrates the University's enforcement of dispossession that is privative in intent. The suspension from the public space of the University was accompanied with orders to campus security for locks to be placed on the hostel room doors of Vemula and his friends. In addition to the material realities of lost accommodations and scholarship funds that poor first-generation students depended on, the symbolic dimensions of removing Dalit students from the University's premises were not lost on students in the ASA. Importantly, their protests were not simply framed as demands for re-entry into the private zones from which they had been jettisoned. More ambitiously volatile and public in scope, they were aimed at 
transforming the political and intellectual climate of their campus by challenging the University's "Brahmin conscience."

In the days following Vemula's death, various political groups on campus joined the ASA to form the Joint Action Committee in order to protest the reinstatement of Vice Chancellor Appa Rao Podile. The VC had a vexed history with Dalit students and soon came to personify the institutional biases behind the cause of Vemula's death. Protesting his re-appointment, the students surrounded his private residence where the administrator was having a meeting with an executive council comprised mainly of ABVP students. In the clashes that ensued, some of the chancellor's private property was destroyed, leading to the involvement of law enforcement. Media reports of the event stressed vandalism and loss of private property as justification for police intervention, with no attempts to address the larger systemic conditions that had motivated the protests to begin with. Several women involved in the demonstrations documented instances of sexual abuse by the police, with one constable demanding that these students "behave like girls, not like prostitutes" (Donthi, 2016). ${ }^{4}$

The ripple effects of Vemula's suicide were not only contained within their local context. Only a few weeks after Vemula's passing, progressive and leftist students at Jawaharlal Nehru University (JNU) began distributing fliers for an event under the aegis of a protest "against the Brahmanical collective conscience." The event combined its challenge to caste Hinduism with the commemoration of the death anniversary of Afzal Guru-one of the accused in the attack on the Indian parliament in 2001, who was sentenced to be hanged by India's Supreme Court without a fair trial. As at the University of Hyderabad, the JNU events were spurred on by students with discrete yet shared investments in interrogating Hindutva and nationalistic projects. Anticipating the power of these inchoate but powerful alliances to undermine the hegemony of Hindu nationalism on college campuses, the ABVP demanded both police and media presence to monitor "treasonous" elements at JNU. When A Zee TV camera captured some groups of students in masks shouting "Pakistan Zindabad" (long live Pakistan) and "Kashmir ki azadi" (freedom for Kashmir) as responses to the ABVP's nationalist chants of Bharat Mata ki Jai (Victory for Mother India), the soundtrack of the footage was superimposed over that of a different student rally headed by Kanhaiya Kumar, the president of the JNU Student Union (the student branch of the Communist Party of India). While his own slogans of "azadi" were uttered in the context of freedom from communal violence and caste hierarchies, the manipulation of the footage made it easy to dismiss any dissident voices as anti-Indian. Kanhaiya and two other students were subsequently arrested under charges of sedition.

16 For Hindu nationalists, JNU epitomized what current BJP UP Chief Minister Yogi Adityanath characterized as "a blot on education." Significantly, to maintain this narrative, the right deployed the rhetoric of dissident sexuality in order to construct the University as a seditious site that warrants regulation and management. For example, a 200-page dossier submitted to JNU's administration prepared by the ABVP along with faculty who were BJP sympathizers contends:

Over one thousand boys and girls students (sic) have been fined from Rs. 2000/- to Rs. 5000/- for consuming alcohol, for indulging in immoral activities in their hostels. On a casual glance at the gates of the hostel one can see hundreds of empty alcohol bottles. Sex workers have been openly employed in hostel messes, where they not only lure JNU girls into their organized racket but also pollute the boys. How come big and high brand cars are moving round the hostels particularly in the 
night hours. Some security staff is also involved in this racket. Freshers are particularly inducted in this ring of vice by luring through money, sex, drugs and alcohol, so that they become tied up with the cause of foreign agencies. (Donthi 2016)

The document goes on to name certain progressive faculty members for "actively recruiting young minds in JNU campus and elsewhere by addicting them to night parties/revelries, alcoholism ... In this process JNU has become a den of organized sex racket..." (Donthi 2016). ${ }^{6}$ One of the contributors to the dossier, Sanskrit professor Hari Ram Mishra, makes links between the need to contain the viral spread of communist ideology on campus and the rampant proliferation of illicit sexual activity: "so many girls are found to be present in the hostel rooms meant only for boys. Who knows where these girls are from?" (Donthi 2016). ${ }^{7}$ Mishra called for University administration to install CCTV cameras in hostels in order to "sanitise the hostels [without which] the university cannot be run properly" (Donthi, 2016). ${ }^{8}$ Similarly, the discourses of sex and sedition are mutually and violently implicated in one another in BJP minister Gyandev Ahuja's concern over "illicit activities" committed "with our sisters and daughters," noting 10,000 butts of cigarettes and 4,000 beedis that were found daily on JNU campus, along with 50,000 pieces of bones left by decadent meat eaters, 2,000 wrappers of chips and namkeen, along with 3,000 used condoms (Donthi 2016). ${ }^{9}$

17 These salacious fictions of student recruitment and decadent drug-fueled orgies mobilize casteist and normative logics of gender and sexuality in order to construct a seditious subject who undermines the progress of nation-building projects. In addition to anxieties surrounding ideological "pollution," the desire to "sanitise" the campus of subversive elements draws on stigmatized taboos regarding the touching of ostensibly impure lower caste bodies-especially relevant given the increased number of Dalit and OBC students who have joined the JNU student population over the past decade. It is this very desire to "cleanse" the University that must physically remove Rohith Vemula and students of the ASA from hostel premises and University space.

It is not without significance that the consternation surrounding uncontainable and hedonistic sex, typically mapped on to women's bodies in these examples, centers around the repeated invocation and explicit imagery of erotic abundance and illicit touch: group sex, decadent parties, "dens" of organized sex, sexual activities in hostels, and perhaps most vividly, the flagrant and shameless panoply of used condoms. The surplus of illegitimate touch in these (imaginary) encounters constitutes the "blot" on the university's public reputation-reminiscent of the dishonor that Siras purportedly brought to AMU by transgressing heteronormative convention. In all invocations of carnal abundance, the filth of sexual activity transgresses the idealized and antiseptic space of privacy, marking the domestic bedroom that functions as a replacement symbol for both the University and the nation. Narratives of excess thus operate as regulative instruments of access-both in terms of which bodies can occupy the physical space of the university, but also how the university itself is re-framed as a zone of privacy that must be guarded against immorality. Sexual excess from the public domain that spills into the private-in this case, the college campus as "sanitized island"-potentially defiles its stainlessness and marks it as seditious.

The above public domains that mark the university as a contested site of struggle appear far removed from the private landscapes of intimate touch that I began with. But if the Indian university, as I have suggested above, is closely tied to the production 
of national and moral culture via exclusions based on caste and normative sex, then the suicides of both Rohith Vemula and Ramchandra Siras can be read as modes of touching that are connected through cognate narratives.

What might it mean then to consider the Siras case, the charges of sedition against JNU students, as well as the protests of the ASA surrounding the death of Rohith Vemula as constitutive of one another rather than discretely comparative or analogous in some simple sense?

\section{Aligarh: text and context}

21 Hansal Mehta's film Aligarh (2016), offers us some clues in responding to this question. Critically and almost universally acclaimed for its sensitive portrayal of Ramchandra Siras, the Marathi poet and professor at Aligarh Muslim University (AMU), Aligarh (Mehta:2016) depicts the events of the last few months of his life, leading up to his mysterious death-declared a suicide by the police. Siras's story made national headlines when he was suspended from his job as a professor of Marathi Literature in the Department of Modern Indian Languages on grounds of "gross misconduct." On the night of February 8, 2010 (referenced in the opening scene of the film), a group of three men forcibly entered the professor's apartment where he was involved in an intimate sexual encounter with a rickshaw puller. After filming the encounter, the mensuspected of being affiliated with a local TV station's camera crew-threatened to expose Siras in the media, claiming they had received complaints about the professor's "homosexual attitude." The very next day, the local media published various reports of the incident, after which the professor was officially suspended from AMU. A public relations officer who represented AMU suggested that the incident was a stain on the character of the University that "no institution of repute [could] overlook" (Narrain 2010). ${ }^{10}$ Along with his suspension, he was also ordered to leave the premises of the University quarters where he resided. On February $24^{\text {th }}$, Siras was served a formal charge sheet with a statement that he had "indulged himself (sic) into immoral sexual activity and in contravention of basic moral ethics while residing in Quarter 21C, Medical College, AMU, Aligarh thereby undermin[ing the] pious image of the teacher community and as a whole, tarnishing the image of the University" (Narrain 2010). ${ }^{11}$

Aligarh's (Mehta:2016) central plot revolves around the emergence of Siras (played by Manoj Bajpayee) as a reluctant activist for the gay rights movement in India just a year after Section 377 of the Indian Penal Code (1860) was declared unconstitutional by the Delhi High Court in the NAZ Foundation vs. Government of National Capital Territory of Delhi judgment (2009). The film poignantly contrasts Siras's bewilderment at his newly imposed public role to the familiar comfort of his private life, spent in the solitude of his apartment surrounded by the joys of poetry and the music of classic Bollywood songs sung by Lata Mangeshkar. Deepu Sebastian (played by Raj Kumar Yadav), a journalist who befriends Siras, serves as his (and the viewer's) mediator between the interior world of solitude and the public arena of law and social justice that he is unwittingly thrust into. The viewer's own will to knowledge is sutured via the Deepu's character, whose initial prurient curiosity is transformed into a more perceptive empathy by the end of the film. It concludes with the April $1^{\text {st }}$ ruling in which the Allahabad High Court ordered Siras's reinstatement at his AMU job along with the mandate to return him to the campus accommodations that were rightfully his until his 
retirement. A week after the landmark legal judgment (Ramchandra Siras vs Aligarh Muslim University 2010), Siras was found dead under mysterious circumstances. Traces of poison in his system raised suspicions that Siras might have been murdered. officially declared a suicide by the police, however, the case was closed and remains unresolved on account of lack of evidence.

The film begins with the primal scene of violation when Siras brings his lover, the rickshaw puller Irfan, up to his apartment. The camera simply remains still, shooting the outside of the apartment without any cuts or edits for a while, disabling any scopic visual consumption of interiority that marks the viewer's desire to see. At least at this very early stage, we are thus denied participation in the technologies of surveillance that invade the professor's privacy by the limits of the camera's gaze. The viewer's will to knowledge is sutured via the character of Deepu, the Express journalist, whose initial prurient curiosity is transformed into empathetic companionship by the end of the film. Deepu's journey in getting to know Siras more intimately constitutes the crux of the film, ultimately functioning as a metonymic substitution for the professor's relationship with Irfan, which can exist only at the margins of the film's diegesis-a point to which I will return shortly.

Aligarh's (Mehta:2016) plot grapples not simply with the story of AMU's suspension and harassment of Siras that thrusts him into the unlikely role of a gay activist, but also with a narrative of solitude and quiet bewilderment at the legal proceedings that ultimately lead to his reinstatement at the University, just a few days before his untimely death. The film bookends and contextually situates the story of Siras through the contrasting legal outcomes surrounding attempts to repeal Section 377 (Indian Penal Code 1860). Aligarh (Mehta:2016) begins by foregrounding its temporal proximity to the 2009 Delhi high court decision (NAZ Foundation vs. Government of National Capital Territory of Delhi 2009) that "declared Section 377 as unconstitutional, effectively decriminalizing homosexuality" (this information appears on screen right after the opening credits). This prefatory context is followed by the first scene of the film that takes place just a couple of months after the high court decision in February 2010. Similarly, the film concludes with a reference to 377 (Indian Penal Code 1860), informing viewers of the Supreme Court's reversal of the high court decision (Koushal vs. NAZ Foundation 2013). The "recriminalization" of homosexuality that ends the film is implicitly tied to the professor's death, which, at a broader level, is also indicative of the death of Indian democracy and the failure of the legal system to guarantee the right to privacy.

25 I am interested in these temporal markers of legalism that frame Aligarh (Mehta:2016) since despite the protagonist's own indifference to an investment in legal proceedings (Siras is seen nodding off during trial proceedings at one moment, and translating his book of poetry from Marathi to English at another), the film underscores violation almost exclusively in terms of legal injury and the failure of the court system to uphold its investment in the professor's right to privacy. When Deepu reassures his colleagues that the Siras case was not simply a "gay issue," but one that was more universally concerned with privacy rights, this ostensibly broader vision is compressed down to a narrowly defined horizon of intimacy. At stake in the Siras case, at least according to the film, is a notion of freedom and citizenship that is predicated on negation-i.e. the right not to be intruded upon by the state. 
Significantly, despite its investment in the preservation of privacy against government intrusion, Aligarh's (Mehta:2016) narrative remains relatively uninterested in a representation of intimacy between Siras and Irfan. The rickshaw-puller-referred to in court simply as "that lower-class Muslim"-ultimately remains the film's absent presence. We see Irfan for a few minutes during the film and only in few scenes via flashbacks-one in which the couple is intruded upon, and the other in which Irfan insists on a darkened room before he and Siras have a sexual encounter. Irfan is literally Aligarh's (Mehta:2016) silent subaltern who has no place in the film's present tense: the script offers him a total of 4 speaking lines. As Aligarh's (Mehta:2016) scriptwriter, Apurva Asrani himself remarks: "The film is about Siras and what happened to him, not their relationship" (2016: Chatterjee).

\section{Queer longing and the voice of nationalism}

The bracketing of Irfan is accompanied by a set of dual replacements that function as proxies for an intimate encounter between the two men. The first substitution comes in the form of a different kind of love story that the film must invest in-between Siras and his passion for the music of Lata Mangeshkar. At various moments in the film, the camera's gaze lingers on its protagonist's face without any directorial or editorial interference. In these scenes, it is Lata Mangeshkar's voice that constitutes the only companion to Siras, exacerbating the sense of solitude and isolation that he experiences. The elongated cinematic time is soundtracked by the Madan Mohan compositions Aap ki Nazron Ne (Anpadh) and Betaab Dil Ki Tamanna (Hanste Zakhm), both iconic tunes sung by Mangeshkar. Director Hansal Mehta has suggested that the film serves as an homage to the Bollywood playback singer-not only because the real-life Siras was a fan of Mangeshkar, but also because her voice, according to him, has functioned as a significant symbolic influence on the gay community in India. Mehta contends: "Her most intimate songs of heartbreak like Chalte Chalte (Pakeezaah) and Jaane Kyun Log (Mehboob Ki Mehndi) connect deeply with the gay community's sense of unfulfilled love and incomplete relationships that they often have to face" (Jha 2016). ${ }^{12}$

However, in this affective ventriloquization of Siras via Mangeshkar, there is more than simply the desire to interpellate queer attachment through embodiments of female iconicity. If the figure of the "lower class Muslim" is written out of the film's diegesis, then what gets folded back into its narrative as a substitute warrants closer examination. In an oft-quoted statement that serves as a testament to the centrality of Mangeshkar as a national archetype of ideal femininity, music director Naushad has suggested that "the very heart of India" (Sundar 2008:144) throbbed in her voice. Naushad's reference has much to do with a post-partition history of playback singing in Bollywood, when popular singers like Noorjehan migrated to Pakistan, enabling a select few like Mangeshkar to dominate the industry in the following decades (Sundar 2008). Thus Mangeshkar's voice served the dual purpose of consolidating an authentic Indian identity post-independence, but also of constructing a pure Hindu voice as representative of the nation, both formally and ideologically. In "Meri Awaz Suno," Pavitra Sundar (2008) contends that Mangeshkar's distinctive vocal style "moved away from the vocal heaviness and nasality of her predecessors, singers like Noorjehan and Shamshad Begum. In effect, her voice was 'cleansed' of all those qualities that would in time be read as markers of decadence, immodesty, and by extension, in the warped 
logic of Indian nationalism, Muslimness" (p. 149). Such modes of ideological "cleansing" had quite real impacts on Mangkeshkar's contemporaries-for example, despite releasing a successful pop record, Bangladeshi artist Runa Laila left the Bombay music industry following rumors that she was an anti-national spy. In her analysis, Sundar (2008) suggests that the timbre of Mangeshkar's voice served as an antithesis to the more "seductive" and "throaty" voices who were relegated to playback singing for vamps and supporting characters. Asha Bhosle, while also enjoying a successful and ascendant career like her sister, often performed songs sung by characters who represented seductive (conflated with "western") qualities. Thus while Bhosle's voice represented what Sundar (2008) characterizes as characteristic of commonplace publicness-"a tinge of the bazaar (or market place)"-Mangeshkar's voice was associated with "the woman in the respectable private sphere" (p. 150). More recently, Mangeshkar's presence has been folded even more explicitly into nationalist and communalist discourse through her public support for both Narendra Modi and the local Shiv Sena government in Maharashtra. In 2017, she publically congratulated Modi and party president Amit Shah on their "shandaar jeet" in the state assembly elections as reported by The Hindustan Times (2017).

Given this history of what Mangeshkar's voice comes to stand for in the ideological needs of nation-building, the significance of her repurposing as a gay icon in Aligarh (Mehta:2016) moves beyond the logics of innocuous fandom for female iconicity. If Mangeshkar serves to index the "heart of India," then the centrality of Siras's attachment functions to suture the gay body to national citizenship so that the potential threat of queerness (historically marked as western and "anti-Indian") gets circumvented. Instead, the legibility of queerness as refracted via Mangeshkar must depend on its proximity to national belonging so that it can be justified as deserving of protection from the law. Mangeshkar's symbolic presence in the film thus confers legitimacy on Siras, compensating for the putative seditiousness of queer public scandal. After all, Siras's transgression was coded as one that tarnished the reputation of a public educational institution in which the University functioned as a microcosm for the nation. Thus instead of aligning Siras with other figures who have performed "seditious" acts on University campuses-Rohith Vemula at the University of Hyderabad or Kanhaiya Kumar at JNU-the folding of Siras into the symbolic realm of essential and authentic Indianness allows for the incorporation of queerness into the nation. If Mangeshkar is the voice of respectable privacy-serving as a foil to the more public sexuality of the vamp, seductress, or prostitute-then Siras's queerness aspires toward the same symbolic intimacy that must be cordoned off from the stigmas of public sexuality. The tethering of Siras to Mangeshkar thus allows queerness to be insulated from the broader counterpublics in which it is implicated. It is not surprising then, that in his comments about the film in The Indian Express, director Hansal Mehta moves away from the queer specificity of the Siras case in order to generalize the film's investment in a universal desire for privacy. He contends: "what happened to Siras could happen to us. This film is not on homosexuality but it is on the right to privacy. No one has the right to interfere in our personal lives" (Anon. 2016). ${ }^{13}$ 


\section{Looking for Irfan: the presence of absence}

room for an investment in a relationship between men-not Siras and Irfan, but Siras and Deepu. Like Mangeshkar, Deepu functions in Aligarh (Mehta:2016) as a kind of substituted switchpoint for Irfan, who gets written out of the film's diegesis. Ironically, it is Deepu himself who tries to locate Irfan in the slums where he resided with his family in an attempt to interview him-a doomed endeavor that results in violent failure when he gets roughed up for his intrepid journalistic persistence. The failed search guarantees the absence of Irfan from the film's temporal present, allowing Deepu to then assume the central role and become the character who most intimately shares narrative space with Siras. In a scene that operates via conventional romanticized visual tropes, we see the two men take an intimate foggy boat ride during which Deepu asks Siras for a selfie together, and mentions how handsome the professor is. While the homoeroticism of the moment is undercut by the clear establishment of Deepu's heterosexuality elsewhere in the film, the substituted triangulation between men functions as a kind of replacement system for the interrogation of class, caste, and communal difference.

31 For example, the romantic filter through which the Deepu/Siras relationship is presented performs a substitution at yet another level by papering over some of the messier narratives around the professor's relationship with Irfan. In press reports containing interviews with Irfan following Siras's death, he intimated that his relationship with Siras was purely a matter of financial convenience. We will never know the "exact" nature of their relationship (is there such a thing?), and to try and uncover some kind of monolithic narrative of authenticity betrays a different kind of will to knowledge: did Irfan suggest a money contract to frame queerness as simply a function of his poverty that sublated desire? A response to such a question can only be speculative, and must, of necessity, be opaque. Besides, this question problematically deflects from the film's framing of Siras through the device of romantic coupledom rather than one of a mutually convenient arrangement between the two men, born not simply out of sexual desire, but also perhaps out of poverty, class, and caste difference. An acknowledgment of the hypothetical financial contract between Irfan and Siras, however, would contaminate the film's hagiographic reading of the latter-not simply through a re-thinking of romantic intimacy between men, but also through the essentially foreclosed account of the discrete social locations that the two men inhabited. In this light, the hints of homoeroticism between Siras and Deepu operate as a kind of repressed metonymy in which intimacy between those two substitutes for the representation of a more dangerously complicated union with Irfan.

\section{Racialization and the politics of privacy violation}

In foregrounding the absence of Irfan, my point is not to make a case for the liberal cause of enhanced visibility via the representation of male intimacy or even gay coupledom; at stake is not the desire to see Irfan and Siras together on screen, as if unmediated visual representation is axiomatically coterminous with radical politics. Instead, I am interested in the ideological terms through which the centering of Siras's story (or hagiography even) and the relative bracketing of Irfan's role gets narrated

South Asia Multidisciplinary Academic Journal, 20 | 2019 
through "racialized" forms of bracketing that haunt narratives of queer progress. In her analysis of sexuality, the state and antisodomy laws in India, Jyoti Puri (2016) argues that governance practices around Section 377 (Indian Penal Code 1860) have not only impacted gay men and hijras, but also Muslims who are seen as "inherently hypersexual and criminal" (p. 75). Drawing on Ania Loomba's arguments on how discourses of religion operate as a form of racialization in postcolonial India, Puri's (2016) ethnography of the Delhi police reveals their insistence on the idea that "unnatural sex crimes are mostly committed by Muslims" (p. 83). For Puri (2016), these contemporary assertions that are mobilized in the context of unnatural sex draw on broader intertwined "genealogies of race and communalism" in which race is not simply the product of phenotypical difference, but of "cultural discourses that produce the body as the site of unequal difference" (p. 85).

з3 It is this logic of racialized bracketing that it is at the heart of Aligarh's (Mehta:2016) arguments for queer freedom-a mode of social belonging that is predicated on privacy, and that can only be guaranteed by the promise of decriminalization. The film's inscription of Siras as the central figure of violation performs a bracketing, for instance, of the real-life Irfan's treatment by the police. Despite registering various first information reports since the death of Siras, none of the University administrators were questioned; instead, the police continued to harass and beat up Irfan, leading to a reported suicide attempt.

There is another sense in which the subsuming of racialization into the logics of privacy is performed through the Siras case. In his analysis of racialized intimacy, David Eng (2010) suggests that for $19^{\text {th }}$ century European notions of personhood, intimacy in a private domestic sphere marked the very essence of subjectivity: "Ideals of privacy in bourgeois domesticity were thus configured as the individual's possession, to be politically protected, as in 'the right to privacy." Eng (2013) thus draws attention to the "history of intimacy as property and possession" (p. 44) that was dependent on slavery and labor of colonized subjects. It is thus ironic that some critics of Section 377 (Indian Penal Code 1860) have adopted the ostensible anti-colonial posture that condemns the law under the aegis of its seemingly archaic colonial genealogies. If we are a postcolonial nation, the argument goes, then Section 377 (Indian Penal Code 1860), a colonial inheritance, is incompatible with the seamless telos toward democratic Indian modernity and postcoloniality. But in founding this argument on right-to-privacy claims, with their implicit investments in domestic property and possession preservation, the argument paradoxically relies on the very colonial logics that it appears to contest. In this light, Aligarh's (Mehta:2016) focus on property and the home as a scene of violation-i.e. the flat on the AMU premises Siras is forced to vacate as a result of his sexual transgressions with Irfan-reconstitutes the primal scene of injustice as one that denies the professor the legal claims over his inalienable property rights. The cleaving apart of sexuality from the racially inflected categories of class, caste, or religion frames this exclusion as abjection from bourgeois domesticity rather than one that has a longer violent history in the Indian state's complicity in the creation of landlessness, residential segregation, housing discrimination, and rural displacement. David Eng (2013) has suggested that "the right to be left alone from state interference, surveillance, and criminalization is a negative liberty that does not ... require the material redistribution of resources" on the part of the state (p. 35). It is worth recalling that, in part, the protests on university campuses began when 
administrators prohibited a group of young Dalit students from using their hostels and the university's public space. Like Siras, Rohith Vemula was displaced from his home on campus. At the time of his death, Vemula was using the hostel room of Uma Maheshwara Rao, a senior ASA leader. But student demands were not limited to the rallying against negative liberties-i.e. the spatial exclusions from campus; instead, they were invested in contesting power through what Dickens Leonard, an ASA member, called "a universal language of discrimination" that is "not just about Dalits," but about creating "a counter political space [that] ... has the potential to question the hegemony of Hindutva politics ... we see it as a coming together of marginalized communities" (Donthi 2016). ${ }^{14}$ Leonard's vision was born out in the alliances that the ASA created with leftist and Muslim student groups-particularly surrounding the controversy informing the execution of Yakub Menon. The ASA opposed capital punishment on grounds of the Indian government's long history of state-sponsored killings of religious and caste minorities. It is this assemblaged "language of discrimination" called for by the ASA through which one can re-think the Siras case. Rather than Mangeshkar and Deepu, we can more usefully read Aligarh (Mehta:2016) through its constitutive absences and exegetic traces-i.e. via the figures of Irfan or even Vemula.

\section{Seditious touching, touching sedition}

35 To conclude then, I wish to return to a moment in the film in which we can retroactively read these absences and melancholic traces in light of "seditious" activities at various centers of higher learning. My critique is not intended as a way to simply fold back that which has been excluded. Instead, it is to consider what epistemological and political possibilities arise when we shift our understanding of the Siras case as one that offers assemblaged frameworks to theorize queer politics beyond matters of privacy violation. In Aligarh (Mehta:2016), the seamlessness of Irfan's replacement with Deepu is threatened only momentarily when professor and journalist share a lunch date during which Deepu offers to share his food with Siras. In response to this gesture, the professor replies: "tumhara haath lag gaya, nah? ... this is non veg, we are brahmins." ("you touched this, no?..."). When Deepu suggests that he doesn't understand religious or caste distinctions, Siras contends that "dharm samajne walle cheez nahi hain" ("religion is not something that you can rationalize")-that rationalizing faith actually sacrifices its purpose. During this exchange, Siras notices a bruise on Deepu's face and questions him about the origins of the wound. The distinguishing mark, as the viewers of the film are already aware, was a consequence of his scuffle during his search for Irfan. I want to read these two moments in Aligarh (Mehta:2016)-the rejection of meat and the recognition of a wound-in close proximity to one another so that they "touch" in ways that than the rest of the film cannot account for.

The proximity of these two moments does not compensate for the missed touches between queer and race/caste/class (or even between Siras and Irfan) in the film. And yet, it is in this moment of the film's acknowledgment of caste difference, however seemingly fleeting, that we can read caste (and Vemula, by association) back into the exegesis of the Siras case in order to re-think the framing of queer politics as one that is predicated on constitutive forgettings. While the brutal violence of caste is 
manifested on a daily basis-for example, through lynchings for the transport or consumption of beef, or through sexual violence against Dalit women-its appearance is also predicated on its perpetual disappearance. In other words, caste is both exceptional but also rendered ordinary to the point that it is relegated to a distant place (rural villages) and time (a less developed past). In "Caste Lives on, and on," Prayaag Akbar (2017) suggests that caste's persistence as a mode of forgetting is enabled by its operations not simply as varna (hierarchy) but also as jati (endogamy). Jati functions as a mode of privatization by hermetically sealing itself off not only through disciplinary acts of prohibition but also through ostensibly caste-neutral and benign rituals of food consumption, arranged marriage, and seemingly harmless "community" practice.

It is worth recalling how the "universal language of discrimination" demanded by Vemula and other members of the ASA was a way to push back against naturalized endogamous rituals on college campuses. The ASA's articulation of a "universal language" was a way to link Brahminical ideology with the projects of Hindu nationalism that implicated both caste and communalist logics. Through this universal language, one can read Aligarh's (Mehta:2016) reference to the politics of food purity as that which maintains caste endogamy; simultaneously it is also that which implicitly references the macabre violence inflicted on Muslims under the aegis of cow protection. This moment of dissonance between Siras and Deepu, however, is quickly resolved through the "violence of forgetting," to invoke Eng again. Irfan's presence in this scene is hinted at only through the "melancholic trace" of the wound that must eventually heal and then disappear. The wound leaves its mark as a reminder of a once violent past that must be expunged from the present. It is not different then, from the bracketing of caste that haunts the nation's political present, which, despite its brutal frames can only be acknowledged via a euphemistic trace-its appearance as disappearance. Thus the recognition of the wound on Deepu's face becomes precisely the moment when it must metaphorically begin to fade. Siras's investments in maintaining caste purity through vegetarianism ultimately only foregrounds benign contradictions-i.e. the Brahminical logics preventing him from touching food "contaminated" by a meat eater that do not, however, stop him from having sex with a non-Brahmin lower-class Muslim. With Deepu, the irony of this investment in caste decorum only functions to humanize Siras's contradictions rather than point to the violence of caste hierarchies.

The attempt to re-think the Siras suicide through the assemblaged lens of the Vemula case and the protests on University campuses cannot be, as I have suggested at the outset, an occasion to analogize between Siras and Vemula, or more broadly, between "queer" and "caste." Instead, through a close reading of Aligarh (Mehta:2016), it would be more appropriate to say that this critique raises speculative questions of what it might mean to think of Siras and Vemula as being "undone by each other" or "given over" (2004:19-20) to one another to use Judith Butler's phrase: i.e. how are they implicated in each other's lives (and deaths) as subjects whose putative transgressions are framed as "seditious?" The politics of relationality marking Butler's (2004) formulation contravenes logics of private intimacy that constitute Aligarh's (Mehta: 2016) vision of sexual citizenship. It is not without significance that in Butler's framework, the possibility of being undone by one another is marked by scent, feel, memory, but also centrally-and significantly, for the purpose of my arguments-by touch. In the context of this reading, "touching" references assemblaged meanings 
simultaneously: the proscriptions around touch that mark caste hierarchies at the University of Hyderabad, or the touching between Irfan and Siras that can only exist beyond the frames of the film (or, at best, at its margins). But it also suggests the speculative touching between Siras and Vemula that places queerness in assemblaged contexts that are more messy and public than what Aligarh (Mehta:2016) allows for. It is only when sexual politics touch these realms that we can begin to imagine how "queer" as a political and epistemological category might challenge rather than simply reproduce neoliberal imperatives of an "incredible" and democratic India. Rather than insisting on queers as model national citizens who are deserving of the nation's benevolent protection, perhaps the time has come to articulate the seditious impulse at the crux of sexual politics.

\section{BIBLIOGRAPHY}

Akbar, Prayaag. 2017. “Caste Lives on, and on.” Aeon, April 20. Retrieved August 17, 2017 (https:// aeon.co/essays/how-india-deludes-itself-that-caste-discrimination-is-dead).

Anon. 2016. "Aligarh about Right to Privacy not Homosexuality: Hansal Mehta." The Indian Express, February 11. Retrieved April 10, 2019 (https://indianexpress.com/article/entertainment/ bollywood/aligarh-about-right-to-privacy-not-homosexuality-hansal-mehta/).

Berlant, Lauren. 2007. “On the Case." Critical Inquiry 33(4):663-72.

Brown, Wendy and Janet Halley. 2002. "Introduction." Left Legalism/Left Critique, edited by W. Brown, J. Halley, R. T. Ford, L. Berlant, M. Kelman, and G. Lester. Durham and London: Duke University Press.

Butler, Judith. 2004. Undoing Gender. New York: Routledge.

Chatterjee, Suprateek. 2016. "Rickshaw Puller is Scared for Life as 'Aligarh' Reveals his Identity as Homosexual.” The Huffington Post, March 2. Retrieved August 3, 2017 (http://

www.huffingtonpost.in/2016/03/02/prof-siras-partner_n_9364260.html).

Donthi, Praveen. 2016. "From Shadows to the Stars: The Defiant Politics of Rohith Vemula and the Ambedkar Students Association." Caravan Magazine, May 1. Retrieved September 3, 2017 (http://www.caravanmagazine.in/reportage/from-shadows-to-the-stars-rohith-vemula).

Eng, David. 2010. The Feelings of Kinship: Queer Liberalism and the Racialization of Intimacy. Durham and London: Duke University Press.

Hindustan Times Correspondent, 2017. "Lata Mangeshkar Congratulates Narendra Modi, BJP, on their 'Shaandar Jeet”' The Hindustan Times, March 11. Retrieved April 10, 2019. https:// www.hindustantimes.com/india-news/lata-mangeshkar-congratulates-narendra-modi-bjp-ontheir-shaandaar-jeet/story-mTESO7mYDJygYl1VjB0dsL.html

Indian Penal Code. 1860. Section 377 in the Indian Penal Code, "Unnatural Offences." Retrieved April 16, 2019 (https://indiankanoon.org/doc/1836974/). 
Indian Penal Code. 1860. Section 124A in the Indian Penal Code, "Sedition." Retrieved April 16, 2019 (https://indiankanoon.org/doc/1641007/).

Jha, K. Subhash. 2016. “That Lata Connect." Syndication DNA, December 1. Retrieved September 6, 2017 (http://dnasyndication.com/showarticlerss.aspx?

nid=rxssuE7A17YNLiKRDgGclxUuCh6ICFIP4tVljqVLmCw=).

Koushal vs. NAZ Foundation, December 11 (2013). Retrieved April 16, 2019 (https://

indiankanoon.org/doc/58730926/).

Krishnan, Kavita. 2016. "Sex and Sedition: What the JNU Dossier Tells Us about the Right-Wing Imagination.” Scroll India, April 27. Retrieved December 3, 2016 (http://scroll.in/article/807268/ jnu-dossier-shows-how-sex-and-sedition-go-hand-in-hand-in-the-right-wing-imagination).

Liang, Lawrence. 2016. "What the Nation Really Needs to Know." YouTube. Retrieved February 11, 2019 (https://www.youtube.com/watch?v=GRwXJmtE2SM).

Mehta, Hansal. 2016. Aligarh. India: Karma Pictures.

Narrain, Arvind, et al. 2010. "Policing Morality at AMU: An Independent Fact Finding Report." Justice for Dr Siras, April 13. Retrieved April 10, 2019 (https://justiceforsiras.wordpress.com).

NAZ Foundation vs. Government of National Capital Territory of Delhi, July 2 (2009). Retrieved April 16, 2019 (https://indiankanoon.org/doc/100472805/).

Puar, Jasbir. 2012. "'I Would Rather Be a Cyborg than a Goddess': Becoming Intersectional in Assemblage Theory.” Philosophia 2(1):49-66.

Puri, Jyoti, 2016. Sexual States: Governance and the Struggle over the Antisodomy Law in India. Durham and London: Duke University Press.

Ramberg, Lucinda. 2016. "Backward Futures and Pasts Forward: Queer Time, Sexual Politics, and Dalit Religiosity in South India." GLQ: A Journal of Lesbian and Gay Studies (Area Impossible: The Geopolitics of Queer Studies, edited by A. Arondekar and G. Patel) 22(2):223-48.

Ramchandra Siras vs Aligarh Muslim University, April 1 (2010). Retrieved April 16, 2019 (http:// elegalix.allahabadhighcourt.in/elegalix/WebShowJudgment.do).

Roy, Arundhati. 2016. "My Seditious Heart: An Unfinished Diary of Nowadays." Caravan Magazine, May 1. Retrieved July 3, 2016 (http://www.caravanmagazine.in/essay/seditious-heart-arundhatiroy).

Sedgwick, Eve. 2003. Touching Feeling: Affect, Pedagogy, Performativity. Durham and London: Duke University Press.

Singh, Anushka. 2018. Sedition in Liberal Democracies. New Delhi: Oxford University Press.

Sundar, Pavitra. 2008. "Meri Awaaz Suno: Women, Vocality, and Nation in Hindi Cinema." Meridians: Feminism, Race, Transnationalism 8(1):144-79.

Tellis, Ashley and Sruti Bala. 2015. The Global Trajectories of Queerness: Re-thinking Same-Sex Politics in the Global South. Leiden and Boston: Brill Rodopi.

\section{NOTES}

1. https://www.youtube.com/watch?v=GRwXJmtE2SM

2. https://www.youtube.com/watch?v=GRwXJmtE2SM

3. http://www.caravanmagazine.in/essay/seditious-heart-arundhati-roy 
4. http://www.caravanmagazine.in/reportage/from-shadows-to-the-stars-rohith-vemula

5. http://www.caravanmagazine.in/reportage/from-shadows-to-the-stars-rohith-vemula

6. http://www.caravanmagazine.in/reportage/from-shadows-to-the-stars-rohith-vemula

7. http://www.caravanmagazine.in/reportage/from-shadows-to-the-stars-rohith-vemula

8. http://www.caravanmagazine.in/reportage/from-shadows-to-the-stars-rohith-vemula

9. http://www.caravanmagazine.in/reportage/from-shadows-to-the-stars-rohith-vemula

10. https://justiceforsiras.wordpress.com

11. https://justiceforsiras.wordpress.com

12.

http://dnasyndication.com/showarticlerss.aspx?

nid=rxssuE7A17YNLiKRDgGclxUuCh6ICFIP4tVljqVLmCw=

13. https://indianexpress.com/article/entertainment/bollywood/aligarh-about-right-toprivacy-not-homosexuality-hansal-mehta/

14. http://www.caravanmagazine.in/reportage/from-shadows-to-the-stars-rohith-vemula

\section{ABSTRACTS}

In this essay, I theorize a relation between sexual and caste politics to consider the interfacing between two suicides on university campuses that made public headlines for different reasons: the Dalit student Rohith Vemula at the University of Hyderabad, and the gay Marathi professor, Ramchandra Siras at Aligarh Muslim University. In analyzing these two cases together, I want to ask what it might mean to retrospectively re-think Siras' case through the language of political and public desire that Vemula's case at the University Hyderabad (UOH) and the Jawaharlal Nehru University (JNU) student protests present. To textually ground my arguments, I analyze the recent film Aligarh (Mehta:2016) praised for its sympathetic portrayal of Siras whose legal fight for privacy (and subsequent suicide) when he is caught having sex with another man constitutes the text's central premise. Through an analysis of the film, I inquire into the occlusions that calls for queer privacy are predicated on. I thus ask: what is lost from queer analytical frames when public domains are disavowed in favor of rights to privacy? In triangulating the notion of privacy with queer politics (via the Siras case) and questions of caste and communalism (through the Vemula case and subsequent student uprisings), this essay gestures toward an articulation of queerness that would move beyond single-issue calls for judicial protection and instead reconsider the "seditiousness" at the heart of a sexual politics.

\section{INDEX}

Keywords: Rohith Vemula, Ramchandra Siras, JNU, sedition, privacy, legalism, nationalism

\section{AUTHOR}

\section{NISHANT SHAHANI}

Women's, Gender, and Sexuality Studies, Washington State University 